\title{
Thailand Foreign Direct Investment to CLMV Countries: Macro Economics Approach
}

\author{
SUJINDA CHEMSRIPONG \\ Faculty of Business Economics and communication, NARESUAN UNIVERSITY, THAILAND. \\ E-mail:sujindac@nu.ac.th
}

\begin{abstract}
Thailand FDI allows countries to enter new markets through imports of goods at lower prices and access to foreign technology because FDI strengthens the economy and increases competition in the era of globalization. Therefore, concerning economic development and regional issues in the context of developing countries Thailand is one of the emergings. Identifying the key factors involved in TFDI is critical for sustainable growth. This study focuses on the factors that define TFDI to CLMV countries using macroeconomic analysis. Quantitative analysis using multiple regression equations on 15 -year time series data, during 2005-2019. The results showed that GDP factors, foreign exchange rates, inflation, the proportion of working-age workers to the country's population, and international cooperation are the major driver of Thailand's outward FDI investment.
\end{abstract}

Keywords: Thailand FDI; Developing Countries; Determinants of FDI; CLMV

JEL Classification: E1, F3 


\section{Introduction}

Under globalization, the creation of new manufacturing bases and the finding of important resources for both labor and capital for lower production costs in their own countries. FDI creates opportunities for trade and economic development of the country and competitiveness as well as the development of a stable financial system with push factors from the country of origin. This includes technological advantages in manufacturing, finance, and managing foreign investment resources and factors attracted by destination countries that need funding for the development of the country, foreign promotion policy, e.g. expanding new markets, seeking natural resources, or increase production efficiency in different countries. TFDI's value in CLMV continues to increase during 20122019. The value of TFDI in CLMV increased to $\$ 7,651.27$ million, from $3,048.90$ million U.S. dollars in Vietnam, Laos 1,930.22 million U.S. dollars, Cambodia 1,370.06 million U.S. dollars, and Myanmar 1,302.09 million USD, considering (BoT, 2019a). The pull factor from CLMV countries are high economic growth rate, working-age workers more than $60 \%$, low labor wages compared to other ASEAN countries, a lot of natural resources commercially exploited such as forests, oil, natural gas, minerals, and water sources that can generate electricity, political stability resulting clear and continuous economic development. It is an opportunity for TFDI in various branches, for example, the manufacturing and food industry investment in Cambodia, energy investment in Lao PDR, business investment in Myanmar, food, textile, and paper products investment in Vietnam, etc. (BoT, 2019b).

The purpose of this study is to examine TFDI with macroeconomic factors in CLMV and study TFDI's key factors to CLMV such as gross domestic products, foreign exchange rates, inflation rate, the proportion of working-age workers, and government policies using developed models. Based on OLI theory by Dunning $(1979,1988)$; Dunning and Gugler, (2008) are models that focus on the advantage of ownership, location ,and the internal positioning of the organizational development position by analyzing the results of various determining that affected TFDI during the period 2005to .2019The rest of the article is following as the review of the literature of the theory and concepts behind the analysis of factors affecting TFDI to CLMV, research findings, conclusions, and recommendations, respectively.

\section{Theoretical Background}

The traditional FDI theory explains why countries want to invest in overseas production instead of exporting products or licensing companies in international markets to take advantage of oil and natural resources. Until the late 1990s, there was a growing interest in multinationals under dunning's international production advantage theory, (1979) is called OLI Paradigm, which explains FDI is as comprehensive and close to the real world.

Many research has been conducted on TFDI on economic development issue, such as Denisia, (2010) Morris, Palakh, (2016), explain that TFDI affects economic development and varies depending on the area and FDI lead to the local company's competitiveness (Kowalewski and Weresa, 2008), the results of the transfer of knowledge in the local market, such as Borensztein et al., (1998). It found negative results in the local market or did not see a link between FDI and the country's economic development, and it differed depending on the economic sector, such as manufacturing, services, textiles, agriculture, mining (Alfaro, 2003). Productivity gives an advantage and produces the necessary products or services. This enables the company to enter new markets through imports of goods from overseas at lower prices and access to foreign technology, enabling the domestic economy to grow and increase competitiveness and increase productivity for local companies. Desai et al. (2005) found a positive relationship between foreign and foreign investment, such as in Lipsey (1995). It found a positive correlation between foreign manufacturing and domestic employment levels and external investment increases productivity and growth abroad. Based on the review literature, it can be divided into factors that determine FDI into 5 important factors as follows: 
1) Marketing factors are factors that attract FDI. If the size of the market in the large investment country will be higher, it will allow multinational corporations to expand production, resulting in the benefit of saving on a scale and make more profit. Ewe-Ghee's research, (2001) found the positive influencing economic growth in developing countries, depending on the size of the company and the operation of MNC. In particular, technology transferred and knowledge spreading. Findlay (1978) found the relationship of MNC suppliers helped increase the efficiency and productivity of local companies. The size of knowledge spread depends on the international technological gap (Kokko et al., 1996) to measure market factors use market size factors and market growth rates.

2) Availability and cost of input factors are factors that each country has different inputs. This leads to price and quality differences such as labor factors, natural resources, etc. This resulted in the relocation of production bases to lower-cost overseas locations or there are inputs that the investor scarcely. Dunning (1988) explained that ownership advantages such as brand names, company-specific assets more than competitors to find a business or manufacturing overseas makes the company profitable. Reducing production costs by seeking raw materials abroad is the result of differences in prices. International inputs and raw materials in different parts of the production process and technology make production more efficient. Overseas production makes the unit cost lower and exports more expensive because of the higher taxes and transportation of overseas production (Shatz and Venables, 2000). So that transportation costs and trade barriers inevitably affect Thailand's FDI.

3) Government-policies factors are the policy that promotes direct international investment, such as tax policy, the level of liberalization of the country (Moran, 1998). If the level of liberalization is low or limited, FDI will move its base to overseas production due to its limited investment policy. Investment stakes and regulations that allow business integration affect FDI and negative performance (Shapiro, 1993; Klein, 1995; Rodrik, 1999). In addition to the technology gap and the level of liberalization, human capital is an important factor in FDI's success in the economic growth of host countries (Borensztein et al., 1998). FDI as MNCs wants to invest in a fast-growing, profitable, and more efficient economy.

4) Investment atmosphere consists of a stable political environment, economic environment factors such as inflation level, foreign exchange rates, country's economic development level, social factors, and attitudes of investors affecting the investment recipient countries. That is the location advantage factor affecting FDI. Location advantage is the reason for the decision to invest directly overseas from multinational corporations. This is the so-called Eclectic Theory of Dunning, (1988) described the difference in the location-specific factor in the international host country and home country.

5) Trade barriers are the trade policy of the investment recipient an important factor that affects the decision between direct investment and exports. If the government of the investment recipient countries has a trade deprivation measure, it affects the decision to invest directly. Instead of exporting to reduce costs and avoid trade barriers. If trade barriers are low, exports get a positive result. Morris, Palakh (2016) found that the FDI outflow determines the size and distance between countries, the potential of the country, free trade (FTAs), GDP growth, and political stability, capital market imperfections (Aliber, 1970) such as international geographic size and distance, marketing capabilities of neighboring countries, FTAs in many countries, GDP growth and political stability. 
Therefore, the most popular macroeconomic factors determine Thailand's FDI are per capita income, liberalization level, interest rate, human capital, technology capabilities, foreign exchange rates, and foreign currency turnover rates (Tolentino, 2008).

\section{Hypothesis and variables used in equations}

From the previous literature of Thailand FDI determining factors. There are several factors: national income per capita, liberalization of the economy for international trade, interest rate, human capital, technology capabilities, exchange rates, and volatility.

The most common factors are the size of the overseas market, local labor costs, capital factors, tax exemption, exchange rate, economic growth abroad, political and economic risks that Thailand has analyzed these factors. Details are as follows:

1. Market size, including market demand and market growth. Theoretically, the large markets overseas can have a positive impact on investment and profitability. Love and Lage-Hidalgo (2000) emphasize that the size of the domestic market affects the selection of Thailand FDI locations. It is possible to take advantage of the size of the economy by saving per size. Therefore, market size can be measured by GDP, GDP per capita, GNP, GNP per capita, or growth rate (Kueh, et.al.2008; and Lee, 2010). Daly \& Tosompark, (2011) found that market size is positively correlated with TFDI, such as GDP, concerning TFDI in the same direction. As GDP increased this means that the ability to produce goods and services in the recipient's country increases. It indicated that the size of the domestic market has increased. As a result, there is an increase in TFDI incentives. The research of Kalotay and Sulstarova (2010) found that market size has a significant and positive influence on TFDI determination, where GDP represents the advantage of OLI-based, ownership and the high correlation between the size of the domestic market and overseas investment. Therefore, GDP is used to represent the size of the domestic market and has a positive relationship with TFDI. Limchaikul, (2003), Kwae- Lao-Yung (2010), and Manityakul, (2003) used GDP to explain the international investment between Thailand and Laos, found a one-way relationship with the volume of foreign direct investment in Laos. Besides, other factors such as the balance of payment factor (BOP) used in Limchaikul, (2003) and found a positive relationship with direct investment as well. Therefore, this research uses GDP as a variable instead of a market size factor and sets up the first hypothesis below:

\section{H1: GDP in CLMV countries has a positive impact on the TFDI in CLMV}

2. Foreign Exchange Rates are an important factor in making foreign investment decisions. When the foreign exchange rates of the recipient increases (the weaker currency) creates an incentive for foreign investors to invest more. Due to the weakening of the currency, investors can exchange currency. To invest, the amount of money has increased, resulting in more investment. On the other hand, if the recipient's foreign exchange rate decreases (appreciation) will result in foreign investors postponing the investment first or not investing. Due to the appreciation of the currency, investors can exchange currency to invest in a reduced amount of money. Countries with strong currencies tend to have a financial advantage over companies from countries with weak currencies, as far as financing or acquisition of foreign operations is concerned (Kohlhagen, 1997). Foreign exchange rates of countries affect the value of direct investment from Thailand to CLMV, in the same direction research by Kyrkillis and Pantelidis (2003) suggests that the appreciation of the Thai baht reduce the competitiveness of exports and increase the ability for domestic companies to invest overseas. Therefore, the appreciation of the exchange rate has a positive effect on TFDI (Limchaikul, 2003; Manitayakul, 2003). Foreign exchange rates are a negative relationship with the amount of FDI in Laos. The amount of TFDI is in line with the country's foreign exchange rate CLMV. As the foreign exchange rate in the CLMV increases (decreased value), there will be an increase in investment from the country. In the study, the exchange 
rate (Cambodian Riel/US dollar) (Lao Gib/US dollar) (Myanmar Jark/US dollar) (Vietnamese Dong/US Dollar) and sets the second hypothesis as below:

\section{H2: The foreign exchange rate in CLMV has a positive effect on TFDI in CLMV}

3. Domestic inflation in CLMV are the factors measuring the change in the goods and services price index in the current year compared to the previous year. Therefore, inflation is a risk factor for the decline in purchasing power. Rising inflation indicates higher domestic product prices. This affected the decisions of foreign investors because when the product is higher, the production cost increases, and the profit from production decreases. The consumer price index ( $\mathrm{CPI})$, therefore is associated with the value of the direct investment in Thailand in the CLMV. In the opposite direction, as the price of goods increases more than the normal price, the cost of producing the goods increases, thus resulting in a lower investment because investors have lower returns. As a result, the investment demand may decrease. Inflation affects the value of direct investment from Thailand to CLMV. In the opposite direction, the exchange rate is the depreciation of the currency in the host country should be added to the host country. The appreciation of the host currency countries reduces FDI (Froot \& Stein, 1991). The effect of exchange rate movements on the flow of FDI has a direct effect on the cost of production in the host country compared to the home country. Therefore, exchange rates, key variables in FDI formulation, and past empirical studies reflect the influence of exchange rate movements in FDI. The research of Aliber (1970, 1971), Caves (1988), and Froot and Stein (1991) studied the flow into countries with low real currency values and flows out of countries with high real currency values, but has not yet concluded. Because the direction and size of the influence are vague. According to Brewer (1993), the government is involved in configuring money and controlling foreign exchange. Interest rate policy exchange and/or other policies. Another theory in this context was proposed by Caves (1988) negative correlation between the level of the exchange rate and the level of FDI in the United States of how exchange rates affect FDI. The impact of cost and revenue on domestic currencies decreased. Import payments generate and reduce net income unless exports expand in the face of depreciation. Similarly, a study by Daly and Tosompark (2011) suggests that if FDI promotes production for international trade exports, it will be the first time that the company has been required to do so. Therefore, the appreciation of the local currency will reduce exports. the higher price and expect to reduce the influx of FDI, if FDI serves the local market, FDI and trade represent each other. The appreciation of the local currency will increase the influx of FDI due to the higher purchasing power of local consumers. There are not many studies in the study. As a result, expected exchange rate measurement uncertainty or fluctuations in FDI literature should be studied as a variable for developing countries with different exchange rate regimes. This research uses inflation in CLMV countries as a defining variant of TFDI and sets the third hypothesis as follows:

\section{H3: Inflation in CLMV harms TFDI in CLMV}

4. Proportion of labor age per population in CLMV country is very much in line with the value of investment from Thailand in the CLMV in the same direction because the recipient country has a large population. There is a demand for goods and services. In the country, the recipients of the capital will have higher volumes. As a result, investors from Thailand can expand the market within the capital. In theory, production costs influence the selection of investment locations. Inputs such as a large number of workers and low wages are good for FDI (Aqeel \& Nishat, 2004). Lower labor costs and higher unemployment attract FDI (Barrell \& Pain 1997). Labor costs are critical to all production costs, negative relationships for this variable include Wang and Swain (1995), Jun and Singh (1996), Wheeler and Mody (1992), Lipsey (1999) indicates whether there may be a positive or significantly influential relationship (Daly and Tosompark, 2011). Lower labor costs in host countries are attractive for foreign investment. Reduced labor costs, there is a positive relationship with the wage rate from the quality of the workers. 
Higher wage rates may. It represents a workforce with higher skills and higher productivity. If you like high-quality workers, high prices, high productivity. Moore (1993) and Love \& Lage-Hidalgo (2000). This research The proportion of labor age per population in CLMV countries affects OFDI from Thailand to CLMV in the same direction, and the fourth hypothesis is as follows.

\section{H4: The proportion of labor age per population of CLMV countries has a positive impact on TFDI in CLMV.}

5. Government policy is an important factor that affects FDI that Banga, (2003), Brewer (1993) explain that different policies affect differently FDI both directly and indirectly through market imperfections, resulting in increased and/or decreasing FDI. Research support by Loree and Guisinger (1995), and Kumar and Pradhan (2002) found both the positive effects of the investment incentives and the negative effect of the performance requirements imposed by the host government. Hines (1996) found that financial incentives significantly affected the decision-making of the premises for FDI that focused on exports. Villela and Barreix (2002) found the policy changes in little influence on FDI and fundamentals do not have much impact on FDI, but the transfer of resources from host countries to foreign companies, and the liberalization of trade and regional trade agreements affects FDI is a major factor. Asiedu, (2002); Globerman and Shapiro (1999) found that a positive effect of free trade agreements on TFDI (Blomstrom and Kokko, 1997). The effect of different taxes leads to TFDI, tax reduction, or tax exemption, as the FDI location determines the operation. Strict government policies affect investment. Brewer (1993) analyze the analysis of state policy on market imperfections and FDI through relevant state policies, the opposite effect of market imperfections and FDI, and the variances of FDI policies between developed and developing countries. Therefore, the provisions of development and policy measures determine the effect of policies on different TFDI countries between developed and developing countries. It has a positive and negative impact on efficiency requirements and negative impacts, effective tax rates of host countries that differ between the period and between developed and developing countries. Besides, non-policy influences such as political stability, cultural distance, GDP per capita, and good infrastructure and quality are the key determinants of TFDI. As a result, this research uses dummy variables of the period before and after the promotion of investment under the ASEAN Comprehensive Investment Agreement ( $\mathrm{ACIA}$ ). The ACIA agreement is an investment agreement that allows investors to invest in ASEAN without any barriers and investment barriers. In particular, the investment has improved the investment environment to be free, more convenient, transparent, and competitive. Under international good practices, it reassures foreign investors to invest in ASEAN and to promote the development of investment in the united states in ASEAN. This will result in foreign investors interested in investing in countries that receive investment and increase the value of the investment. In the study, $\mathrm{ACIA}=0$ was the period before the promotion of investment under the agreement (2005-2008) and $\mathrm{ACI} A=1$ was the period after the promotion of investment under the agreement (2009-2019).

\section{H5: The ACIA of CLMV has a positive effect on TFDI in CLMV countries}

\section{Analysis of Data and Statistics used}

This study uses quantitative analysis to find key factors affecting TFDI from Thailand to CLMV.

Secondary data was analyzed between 2005 to 2019 for 15years from the Bank of Thailand, World Bank, and from other studying countries: Cambodia, Lao PDR, Myanmar, and Vietnam. Using the ordinary least squarer equation (OLS) by the EViews statistics software for the calculation to analyze variables in the model: TFDI $=f(G D P, I N F, E X, L P, A C I A)$, which TFDI is the value of Thailand's foreign direct investment to the CLMV country, GDP is the gross domestic product value of CLMV, INF is the domestic inflation rate of CLMV, EX is the foreign currency exchange rate between Thailand and the 
CLMV, LP is the proportion of labor age per population in CLMV countries.ACIA is before and after the promotion of investment under the agreement and $C$ is Cambodia, $L$ is Laos, $M$ is Myanmar and $V$ is Vietnam. Multicollinearity problems have been tested by finding a correlation between independent variables and independent variables used correlation matrix heteroskedasticity problem test, find independent variable relationships with variables based on whether there is a statistically significant correlation. Heteroskedasticity test and autocorrelation test for the independence of discrepancies by testing Durbin-Watson values.

\section{Result and Discussion.}

There are four models as follows:

1. The Model of TFDI to Cambodia (TFDI) is a variable in the value of Cambodia's gross domestic product $\left(\mathrm{GDP}_{\mathrm{c}}\right)$, inflation in Cambodia $\left(\mathrm{INF}_{\mathrm{C}}\right)$, Cambodian Riels foreign exchange rates per US Dollar $\left(\mathrm{EX}_{\mathrm{C}}\right)$, and the period before and after the promotion of investment under the agreement (ACIA). Therefore, the value of investment from Thailand to Cambodia is $84.06 \%$ and $15.93 \%$ is the result of changes in other variables that are not analyzed. Therefore, the equation of TFDI to Cambodia is:

$$
\begin{aligned}
& \text { TFDI }_{C}=36077.69+43.98071 G D P *_{C}-12.57738 I_{N F}{ }^{c}-8.898594 E X{ }^{*} c+620.4640 A C I A * \\
& (\mathrm{t} \text {-test })=\left(\begin{array}{lllll}
(4.229811) & (1.523901) & (-0.734675) & (-4.343563)
\end{array}\right.
\end{aligned}
$$

2. The Model of TFDI to Laos (TFDIL) is a variable in the gross domestic product value of Lao PDR $\left(G D P_{L}\right)$, inflation in Lao PDR $\left(I_{\mathrm{L}}\right)$, and the period before and after the promotion of investment under the agreement $(A C I A)$. The variance of variables by Thailand to Laos was $79.47 \%$, the remaining $20.52 \%$ as a result of changes in other variables not analyzed. Therefore, the equation of TFDI to Laos is:

$$
\begin{gathered}
\mathrm{TFDI}_{\mathrm{L}}=-700.6142+147.6421 \mathrm{GDP} *{ }_{\mathrm{L}}-3.542436 \mathrm{INF} *_{\mathrm{L}}+472.6395 \mathrm{ACIA} * \\
\text { (t-test) }=(-1.625661) \quad(3.382235) \quad(-0.091986) \quad(1.907440)
\end{gathered}
$$

Table :1Analysis of Thailand foreign direct investment Models to CLMV

\begin{tabular}{|c|c|c|c|c|}
\hline Independent V. & M1: TFDIC & M2: TFDI & M3: TFDI & M4: TFDI $_{\mathbf{M}}$ \\
\hline TFDI & 36077.69 & -700.6142 & -21227.57 & -2617.460 \\
(t-test) & $(4.229811)$ & $(-1.625661)$ & $(-3.662506)$ & $(-3.566220)$ \\
\hline GDP & $+43.98071^{*}$ & $+147.6421^{*}$ & & $+27.72022^{*}$ \\
(t-test) & $(1.523901)$ & $(3.382235)$ & & $(5.086330)$ \\
\hline INF & $-12.57738^{*}$ & $-3.542436^{*}$ & & $+8.564167^{*}$ \\
(t-test) & $(-0.734675)$ & $(-0.091986)$ & & $(0.334766)$ \\
\hline ACIA & $+620.4640^{*}$ & $+472.6395^{*}$ & $+457.7402^{*}$ & $+393.6570^{*}$ \\
(t-test) & $(2.287164)$ & $(1.907440)$ & $(2.803414)$ & $(1.005039)$ \\
\hline EX & $-8.898594^{*}$ & & $1.006361^{*}$ & \\
& $(-4.343563)$ & & $(6.535981)$ & \\
\hline LF & & & $+450.1137^{*}$ & \\
\hline$R^{2}$ & 0.886160 & 0.838719 & 0.898027 & 0.870280 \\
\hline Adjust R & 0.840624 & 0.794733 & 0.870216 & 0.834902 \\
\hline Durbin-Watson stat & 2.805116 & 0.884441 & 2.689030 & 1.607778 \\
\hline Prob(F-statistic) & 0.000104 & 0.000115 & 0.000009 & 0.000035 \\
\hline
\end{tabular}

Source: Data from World Bank (2020), and analyzed by the author

3. Model of TFDI to Myanmar (TFDI $I_{M}$ is a foreign exchange rate variable against the U.S. dollar. ( $E X_{M}$ ), the proportion of the population of the age workers per total population $\left(\mathrm{LF}_{\mathrm{M}}\right)$, and the period before and after the promotion of investment under the agreement ( $A C I A)$. The variance of variables by 
Thailand to Myanmar was $87.0216 \%$ and $12.9784 \%$ was the result of changes in other variables that were not analyzed. As a result, the equation for TFDI to Myanmar is shown as follows:

$$
\begin{gathered}
\mathrm{TFDI}_{\mathrm{M}}=-21227.57+1.006361 \mathrm{EX}{ }^{*} \mathrm{M}+450.1137 \mathrm{LF}^{*}{ }_{\mathrm{M}}+457.7402 \mathrm{AClA} * \\
(\mathrm{t} \text { - test })=(-3.662506)+(6.535981)+(3.686026) \quad+(2.803414)
\end{gathered}
$$

4. Model of TFDI to Vietnam (TFDIV) is a variable in the value of the gross domestic product within Vietnam ( $\left.G D P_{v}\right)$, inflation in Vietnam ( $\left.E X_{v}\right)$, and the period before and after the promotion of investment under the agreement ( $\mathrm{ACI} A$ ). The variance of investment value from Thailand to Vietnam was 83.4902 percent, while $16.5098 \%$ was the result of changes in other variables that were not analyzed. As a result, the equation for TFDI to Vietnam is:

$$
\begin{array}{r}
\text { TFDI }_{V}=-2617.460+27.72022 \mathrm{GDP}^{*}{ }_{\mathrm{V}}+8.564167 \mathrm{INF} * \mathrm{v}+393.6570 \mathrm{ACIA} * \\
(\mathrm{t}-\mathrm{test})=(-3.566220)(5.086330) \quad(0.334766)
\end{array}
$$

\section{Discuss the Findings}

The EX, INF, LY, and ACIA factors are the key driver of TFDI in Thailand to CLMV. This section will discuss the findings of factors that determine foreign direct investment from Thailand to the CLMV country based on the following assumptions:

The first assumption is the value of gross domestic product CLMV affects the value of direct investment from Thailand to CLMV countries in the same direction. The results showed that the gross domestic product value of Lao PDR and Vietnam. The company has a relationship in the same direction as the value of direct investment from Thailand. In Limchaikuls' (2003) research, gross domestic product influenced foreign direct investment in Indochina and the Union of Myanmar and consistent with Manityakul s'(2003) research that gross domestic product in Thailand is a factor affecting foreign direct investment. Consistent with the research by Suka (2005), the value of the gross domestic product within Thailand is a determining factor in foreign investment in the retail business in Thailand.The same relationship with Thailand's direct investment value is significant at a significant level of 0.05 to invest in Cambodia, Laos, and Vietnam, except Myanmar. When GDP in Cambodia, Laos, and Vietnam, that 1unit change will result in Thailand increased investing in Cambodia as 43.980, 147.642, and 27.720 USD million, respectively. This is consistent with the hypothesis that the value of the gross domestic product is higher, will motivate investors from Thailand to invest more as well, and have a positive relationship with OFDI, consist with the results of the Masron and Shabudin (2010) and Saad, et.al. (2014) studied in Malaysian case.

The second assumption is that CLMV domestic inflation affects the opposite direction of the value of FDI from Thailand to CLMV countries. The results showed that inflation within Cambodia, Lao PDR, and Vietnam have no effect on the value of FDI from Thailand and didn't meet the second assumption. In contrast with Kwea-Lao-Yung s'(2003) research that inflation in Laos has an in a different direction to direct investment from Thailand and the research by Manityakul (2003) that inflation within Thailand is in line with the value of FDI. Inflation (INF) was found to have a negative relationship with TFDI in the Cambodia and Lao models, resulting in a decrease in foreign investment from Thailand to Cambodia and Laos 12. 577and 3.5424 USD million, respectively.

The third assumption is that the foreign exchange rate of CLMV countries affects the value of FDI from Thailand to CLMV countries in the same direction. The results showed that the Cambodian foreign exchange rate against the U.S. dollar. There is a correlation in the opposite direction to the value of FDI from the country. This is in line with the research by Manityakul (2003) on the foreign exchange rate of Baht per US dollar. The impact on the value of FDI in Thailand in the opposite direction. Myanmar 
foreign exchange rate per the the USdollar has a relationship in the same direction as the value of FDI from Thailand. This is in line with the research by Suka (2005) that the foreign exchange rate in Baht per U.S. dollar affects the amount of FDI in the retail business in Thailand in the same direction. If the Baht increases (Baht weakens) the value of FDI in Thailand will increase as the value of Thai property is lower. As a result, foreign countries are more interested in investing. The exchange rate was found to have a negative relationship with TFDI in the Cambodian model. The exchange rate between the US dollar and silver in Cambodia 1unit change, resulting in FDI from Thailand to Cambodia. Decrease 8.898594 in line with the results of the study, there is a positive correlation in Myanmar Kueh, et.al (2014); and Goh and Wong (2011) in Malaysia and Seungjin, (2000) in Korea.

The fourth assumption is that the proportion of the number of labor ages per population in CLMV countries affects the value of direct investment from Thailand to CLMV countries in the same direction. The results showed that the proportion of the number of labor age to the total population in Myanmar. The company has a relationship in the same direction as the value of FDI from Thailand which is consistent with Khinkwae (2008) and Kwae-Lao-Yung s'(2003) research. The population was associated with the value of FDI in Lao PDR because of the increasing population. The number of workers will also increase, making it possible to produce more goods for investors and positively affects investors who invest. The proportion of workers in the workforce was found a positive effect on TFDI, the large proportion and cheap labor, attracting FDI from Thailand to Myanmar by 450.1137 US dollars consist with the study of Morris (2016) which found that more resources were being sought.

The fifth assumption is the period before and after the promotion of investment under the ACIA agreement. This affects the value of FDI from Thailand to CLMV countries. The results showed that only Cambodia and Myanmar at the time after the promotion of investment under the ACIA agreement affected the value of FDI from Thailand. Since Cambodia and Myanmar's investment promotion policy, benefits are not able to attract FDI as well as they should. But both countries still have natural assets and other factors that investors are interested in. So it can be seen that Cambodia and Myanmar ACIA agreement, which allows investors to access invest in ASEAN without any barriers and investment barriers. As a result, the value of TFDI has increased. Government policy promoting investment under the agreement $(\mathrm{ACI} A)$ affects the value of TFDI.

\section{Conclusion and Suggestion}

The key factors of TFDI is an important strategy for Thailand's development and help to restructure the economy to be competitive and grow. As a result, Thai businesses have adapted to increase their production capacity to grow and compete for seeking new markets or maintain the same market share with large or high growth trends, natural resources and access to cheaper raw materials, labor in the country, and increase production efficiency, as well as the pursuit of new technologies. Also, TFDI helps the balance of inflow and outflow payment for expanding the market, seeking natural resources, reducing production costs, seeking technology and brand. CLMV countries rely on foreign investment. High economic growth and business opportunity attract investors from Thailand to invest. Therefore, this study aims to study the factors prescribed by TFDI to CLMV and the period before and after and after the promotion of investment under the ACIA agreement what factors determine TFDI and the relationship in each CLMV country, during 2019-2005based on Dunning's eclectic theory of OLI and new trade theory. It was found that GDP, INF, EX, ACIA, and LF were the important factors that increased TFDI.

There are suggestions that the annual data information taken in this study is the most complete number at the moment, which is considered to be a small number and may affect the accuracy of data analysis. If a large amount of data is taken for study and analysis, it may be possible to see the impact of each factor that is more accurate and accurate on the value of the direct investment in Thailand. In 
this study, there were only five factors that led to the study of how it relates to the value of direct investment from Thailand. Due to the limitations and frustration of the search of each country in the clmv country that is not collected. Therefore, if there is a study next time and there is more information on the factors that are collected, those who do the study can be able to use the theory in various investments. Make decisions on variable selection.

\section{References}

1. Alfaro. L. (2003), Foreign direct investment and growth: does the sector matter? Harvard Business School, USA.

2. Aliber, R. Z. (1971). The multinational enterprise in a multiple currency world. The multinational enterprise, 49-56.

3. Aliber, R. Z. (1970). A theory of direct foreign investment. The international corporation, 17-34.

4. Aqeel, A., \& Nishat, M. (2004). The Determinants of Foreign Direct Investment in Pakistan. The Pakistan Development Review, 43(4), 651-664

5. Asiedu, E. (2002). On the determinants of foreign direct investment to developing countries: is Africa different?. World Development, 30(1), 107-119

6. Banga, R. (2003). Impact of government policies and investment agreements on FDI inflows. Indian council for research on international economic relations, 1-43

7. Barrell, R., \& Pain, N. (1997). Foreign Direct Investment, Technological Change, and Economic Growth within Europe. Economic Journal, 107(445), 1770-86

8. Borensztein, E., De Gregorio, J., Lee, J.W. (1998), How does foreign direct investment affect economic growth? Journal of International Economics, 45, 115-135.

9. BoT (2019a). Get to know CLMV - Interesting Economic Opportunities: Retrieved 20 Aug 2020.https:/www.bot.or.th/Thai/AboutBOT/InternationalCooperation

10.BoT (2019b). Thailand's direct investment abroad (Outflow) classified by country/economic zone and business type of Thai investors: Retrieved 20 Jul 2020 from https:/www.bot.or.th/App/BTWS_STAT/statistics/ReportPage.aspx?reportID=848\&lang uage=th

11.Brewer, T. L. (1993). Government policies, market imperfections, and foreign direct investment. Journal of International Business Studies, 24(1), 101-120.

12.Blomstrom, M., \& Kokko, A. (1997). Regional integration and foreign direct investment (No. w6019). National Bureau of Economic Research.

13.Caves, R. E. (1988). Exchange-rate movements and foreign direct investment in the United States. Harvard Institute of Economic Research, Harvard University.Chopra \& Sachdeva, 2014,328

14.Daly, K. \& Tosompark, C. T. (2011). Determinants of foreign direct investment in Thailand. Contemporary Studies in Economic and Financial Analysis, 93, 709-718

15.Denisia, V. (2010), Foreign direct investment theories: an overview of the main FDI theories, Academy of Economic Studies Bucharest, European Journal of Interdisciplinary Studies, 2(2), 104 109.

16.Desai, M.A., Foley, F., Hines Jr., J., R. (2005). "Foreign Direct Investment and the Domestic Capital Stock." American Economic Review Papers and Proceedings 95(January): 33-38.

17.Dunning, J.H. (1979), Toward an eclectic theory of international production: some empirical tests, Journal of International Business Studies, 11(1), 9-31.

18.Dunning, J.H. (1988), The eclectic paradigm of international production: a restatement and some possible extensions, Journal of International Business Studies, 19(1), 1-31.

19.Dunning, J.H, and P. Gugler (2008). International Business FDI, Location and Competitiveness. eds. Anderson $\mathrm{U}$. and Pedersen $\mathrm{T}$. 
20.Ewe-Ghee, L. (2001), Determinants of, and the relation between, foreign direct investment and growth: a summary of the recent literature, IMF Working Paper, WP/01/175.

21.Findlay, R. (1978), Relative backwardness, direct foreign investment, and the transfer of technology: a simple dynamic model, The Quarterly Journal of Economics, 92(1), 1-16.

22.Froot, K. A., \& Stein, J. C. (1991). Exchange Rates and Foreign Direct Investment: An Imperfect Capital Markets Approach. The Quarterly Journal of Economics, 106(4), 1191-1217.

23.Goh, S.K., Wong, K.N., (.2011Malaysia's outward FDI: the effects of market size and government policy. Journal of Policy Modeling 33, .510-497

24.Globerman, S., \& Shapiro, D. M. (1999). The Impact of Government Policies on Foreign Direct Investment: The Canadian Experience. Journal of International Business Studies, 30(3), 513-532.

25. Hines Jr, J. R. (1996). Tax policy and the activities of multinational corporations (No.w5589). National Bureau of Economic Research.

26.Jun, K. W. \& Singh, H. (1996). The determinants of foreign direct investment in developing countries. Transnational Corporations, 5, 67-105.

27.Kalotay and Sulstarova (2010 Kalotay, Kalman, and Astrit Sulstarova. 2010. "Modelling Russian outward FDI." Journal of International Management 16(2): 131-142.

28. Khinkwae, K. (2008). Factors affecting direct investment of Thailand in new ASEAN member States. Master of Economics Thesis, Kasetsart University.

29.Klein, K. (1995), General Motors in Hungary: the corporate strategy behind Szentgotthard, Georgetown University, Pew Economic Freedom Fellows Program, Washington.

30.Kokko, A., Tansini, R., Zejan, M. (1996), Local technological capability and spillovers from FDI in the Uruguayan manufacturing sector, Journal of Development Studies, 34, 602-611.

31.Kowalewski, O., Weresa, M.A. (2008), The role of foreign direct investment in the economy, in: Technology transfer through foreign direct investment: the case of Poland, 1st edn, Rainer Hampp Verlag, Munich, 127-143.

32.Kohlhagen, S.W (1997). Exchange Rate Changes, Profitability and Direct Foreign Investment, Southern Economic Journal, 44: 376-383

33.Kumar, N., \& Pradhan, J.P. (2002). FDI, externalities and economic growth in developing countries: some empirical explorations and implications for WTO negotiations on investment (Vol. 27). RIS Discussion Paper.

34.Kueh, S.H., Puah, C.H., Apoi, A., (2008). Outward FDI of Malaysia: an empirical examination from macroeconomic perspective. Economic Bulletin 6, 1-11.

35.Kueh, J. S., Puah, C., \& Liew, V. K. (2014). Macroeconomic determinants of direct investment abroad of Singapore. International Economics, Engineering Economics, 25(1), 72-81.

36.Kwae-Lao-Yung, L. (2010), Factors that determine the direct investment of Thai investors in the Republic Lao People's Democracy: Master of Economics Thesis, Khon Kaen University.

37. Kyrkillis and Pantelidis (2003 Kyrkilis, D. \& Pantelidis, P. 2003, 'Macroeconomic Determinants of Outward Foreign Direct Investment', International Journal of Social Economics, vol. 30, no. 7, pp. 827-836.

38.Lee, C. G. (. (20100utward foreign direct investment and economic growth: Evidence from Japan. Global Economic Review, (3)39, .326-317

39.Limchaikul, N. (2003). Direct Investment in Indochina and Myanmar: Thailand's Investment Opportunities: Master of Economics, Ramkhamhaeng University.

40.Lipsey, R. E. (1999). The location and characteristics of US affiliates in Asia (No. w6876). National Bureau of Economic Research.

41.Lipsey, R.E. (1995). Outward Direct Investment and the US. Economy. 7-42. 
42.Loree, D. W. \& Guisinger, S. E. (1995). Policy and non-policy determinants of US equity foreign direct investment. Journal of International Business Studies, 26(2), 281-299.

43.Love, J. H., \& Lage-Hidalgo, F. (2000). Analyzing the determinants of US direct investment in Mexico. Applied Economics, 32(10), 1259-1267.

44. Manitayakul, A. (2003). Factors affecting Thailand's foreign direct investment: Master of Economics Thesis, Ramkhamhaeng University.

45. Masron,T.A. and Shabudin, A.S. (2010). Push Factors' of outward FDI: Evidence from Malaysia Journal of Business \& Policy Research 5(1): 54-68. Retrieve from http:/wbiaus.org/5.Tajul.pdf.

46.Moran, T. (1998), Foreign direct investment and development: The new policy agenda for Developing countries and economies in transition, Institute for International Economics, Washington, D.C.

47.Morris, S., Palakh, J. (2016), Determinants of outward FDI: anempirical analysis of OECD source countries, retrieved from SSRN:https://Ssrn.com/abstract=2733040.

48. Moore, M. O. (1993). Determinants of German manufacturing direct investment: 1980-1988. Weltwirtschaftliches archiv, 129(1), 120-138.

49.Rodrik, D. (1999), The new global economy and developing countries: making openness work, Policy Essay No. 24, Overseas Development Council, Washington, D.C.

50.Saad, R.M., A.H.M. Noor, A.H.S.M. Nor (2014). Developing Countries' Outward Investment: Push Factors for Malaysia.Procedia-Social and Behavioral Sciences. 130(15), 237-246 retrieve from https://www.sciencedirect.com/science/journal/18770428

51.Seungjin K. (2000). "Effects of Outward Foreign Direct Investment on Home Country Performance: Evidence from Korea." In The Role of Foreign Direct Investment in East Asian Economic Development, eds.Takatoshi Ito and Anne O. Krueger.Chicago:295-319

52.Shapiro, H. (1993), Automobiles: from import substitution to export promotion in Brazil and Mexico, in D. Yoffie (Ed), Beyond free trade: firms, governments, and global competition, Harvard Business School Press, Boston, 193-250.

53.Shatz, H., Venables, A.J. (2000), The geography of international investment, World Bank Policy Research Working Paper No. 2338.

54.Tolentino, P.E. (2008), The determinants of the outward foreign direct investment of China and India: whither the home country? United Nation University, Maastricht Economic and Social Research and Training Centre on Innovation and Technology, UNU-MERIT, Working Paper Series \#2008-049, ISSN 1871-9872.

55.Villela, L., \& Barreix, A. (2002). Taxation and investment promotion background note for global economic prospects. Washington: Inter-American Development Bank.

56.Wang, Z. Q., \& Swain, N. J. (1995). The determinants of foreign direct investment in Transforming economies: Empirical evidence from Hungary and China. Weltwirtschaftliches Archiv, 131(2), 359382.

57.Wheeler, D., \& Mody, A. (1992). International investment location decisions: The case of US firms. Journal of international economics, 33(1), 57-76.

58. World Bank. (2020). GDP, inflation, exchange rate, labor force, in Cambodia, Lao, Myanmar and Vietnam. Retrieves on 1 November 2020 from https://data.worldbank.org/indicator/ 